\title{
Spontaneous and bilateral avascular necrosis of the navicula: Müller-Weiss disease
}

\author{
Navikulanın spontan ve iki taraflı avasküler nekrozu: Müller-Weiss hastalığı \\ Erdem Aktaş, MD.,' Tacettin Ayanoğlu, MD., ${ }^{2}$ Yasin Hatipoğlu, MD., ${ }^{2}$ Ulunay Kanatlı, MD. ${ }^{2}$ \\ ${ }^{1}$ Department of Orthopaedics, Ankara Training and Research Hospital, Ankara, Turkey \\ 2Department of Orthopaedics, Medical Faculty of Gazi University, Ankara, Turkey
}

\begin{abstract}
Although, trauma, foot deformity (pes planovalgus), systemic diseases such as diabetes mellitus and lupus, drugs (steroids, antineoplastic) and excessive alcohol consumption have all been accused in the etiology of avascular necrosis of the tarsal bones, spontaneous avascular necrosis of the navicular bone, especially in adults, is a rare entity. In this article, we report a 50-year-old female patient with bilateral, spontaneous avascular necrosis of the navicular bone and related severe talonavicular arthrosis. Clinical and radiological findings were concordant with MüllerWeiss disease, which is a rare disease with complex idiopathic foot condition of the adult tarsal navicular bone characterized by progressive navicular fragmentation and talonavicular joint destruction. The patient was successfully treated with twostaged bilateral talonavicular arthrodesis.
\end{abstract}

Keywords: Avascular necrosis; Müller-Weiss disease; navicular bone.

Avascular necrosis (AVN) of the tarsal bone is a relatively rare clinical entity. In general, disruption of the microvascular and macrovascular system is known to be the major mechanism for AVN. Trauma, sickle cell anemia, coagulopathies, steroids, excessive alcohol consumption, Gaucher's disease, dysbaric osteonecrosis, hypo fibrinolysis, thrombophilia, systemic lupus erythematosus, human immunodeficiency virus (HIV) and spontaneous development are described to be the etiological factors. ${ }^{[1,2]}$ A disease called Müller-Weiss was defined in adults, which is distinctive from Koehler's disease, since AVN of the tarsal navicular bone was found to be bilateral with no spontaneous resolution. ${ }^{[3]}$

\section{$\ddot{O} Z$}

Her ne kadar travma, ayak deformitesi (pes planovalgus), diabetes mellitus, lupus benzeri sistemik hastalıklar, ilaçlar (steroid, antineoplastik) ve aşırı miktarda alkol tüketimi tarsal kemik avasküler nekroz etiyolojisinde suçlansa da naviküler kemiğin spontan avasküler nekrozu, özellikle erişkinlerde, nadir görülen bir durumdur. Bu yazıda, iki taraflı spontan gelişen naviküler kemikte avasküler nekroz ve ileri derecede talonaviküler artrozu olan 50 yaşında bir kadın olgu sunuldu. Klinik ve radyolojik bulgular; erişkin tarsal naviküler kemikte, progresif fragmantasyon ve talonaviküler eklem hasarı ile seyreden, nadir görülen, kompleks, idiopatik bir hastalık olan Müller-Weiss hastalığ 1 ile uyumlu bulundu. Hasta, iki aşamalı olarak talonaviküler artrodez ile başarıyla tedavi edildi.

Anahtar sözcükler: Avasküler nekroz; Müller-Weiss hastalığı; naviküler kemik.

Either resulting from the above-mentioned various etiological factors or spontaneous development, AVN in the tarsal bones ends up in osteoarthritis and deformity in a short period of time, due to the alteration of foot biomechanics and load distribution. Various treatment modalities have come into sight related to different stages of the disease. Surgical interventions are advocated for its treatment since vast majority of the cases are resistant to conservative methods. During the early stages of the disease core-decompression may be beneficial, but when collapse occurs with mid-foot pain while ambulating; reconstruction with allografts, autografts, ankle arthroplasty and arthrodesis are options that are

\footnotetext{
- Received: January 19, 2016 Accepted: March 03, 2016
}

- Correspondence: Erdem Aktaş, MD. Ankara Eğitim ve Araştırma Hastanesi Ortopedi ve Travmatoloji Kliniği, 06340 Altındağ, Ankara, Turkey Tel: +90 312 - 5953000 Fax: +90312 - 3633396 e-mail: drerdem2007@gmail.com 
recommended with mid-term favorable functional outcomes. ${ }^{[4-6]}$

We report a case with bilateral spontaneous AVN of the navicular bone for its instructive features.

\section{CASE REPORT}

A 50-year-old female patient was admitted with ankle and mid-foot pain while ambulating. Her complaints had a three-year history and were exacerbated for the last three months and she was now able to ambulate only by using crutches. The patient did neither reveal a family history with similar complaints, nor systemic steroid usage, alcohol consumption, trauma, diabetes, rheumatoid arthritis and systemic lupus erythematosus. Physical examination revealed deformity on the dorsomedial aspect of the talonavicular joint and tenderness with palpation. Range of motion was restricted and painful in both ankles with $5^{\circ}$ dorsiflexion and $20^{\circ}$ plantar flexion. Body mass index was $25.40 \mathrm{~kg} / \mathrm{cm}^{2}$, total blood count, acute phase reactants and rheumatological parameters were found to be between normal ranges. A written informed consent was obtained from the patient.

Radiographs showed minimal bilateral subchondral collapse, cystic, sclerotic changes in the neck of talus, sclerotic collapse in the lateral aspect of the navicula and comma-like shaped navicular bone due to decreased coverage of the navicula. Subchondral sclerosis, irregularity, narrowing of the talonavicular joint and apparent osteophyte formation was suspected in both talonavicular joint (Figure 1). The above-described radiological findings of the talus and navicular bone were found to be concordant with AVN and advanced bilateral arthrosis of the talonavicular joint.

A two-stage bilateral talonavicular arthrodesis was planned for its treatment. The patient being under spinal anesthesia, after inflating the tourniquet, dorsomedial approach was preferred to visualize the left talonavicular joint. The capsule and periost were excised respectively and the navicular bone was exposed. Navicular cortex was found to be greyish and sclerotic, which was congruent with AVN findings. Following corticotomy, decancellation was performed using a curate and burr. The defect (left $2 \times 2 \times 1.5 \mathrm{~cm}$, right $2 \times 1,5 \times 1$, and $5 \mathrm{~cm}$ ) was filled with autogenous iliac bone graft. Arthrodesis was achieved by using two $4.0 \mathrm{~mm}$ cannulated screws, positioned from the navicular tubercle towards the talar neck. Dorsal osteophytes of the talus and navicular bone were excised meticulously. Postoperative immobilization was achieved using an ankle-foot orthosis for eight weeks. Partial weightbearing was initiated at the end of eight weeks and full weight-bearing was allowed at the end of the three-month follow-up period. Fusion at the talonavicular joint was achieved at sixth month; the patient was pain free and was able to ambulate independently (Figure 2, 3).

\section{DISCUSSION}

Although talus is susceptible to AVN due to insufficient collateral circulation, thin nutrient
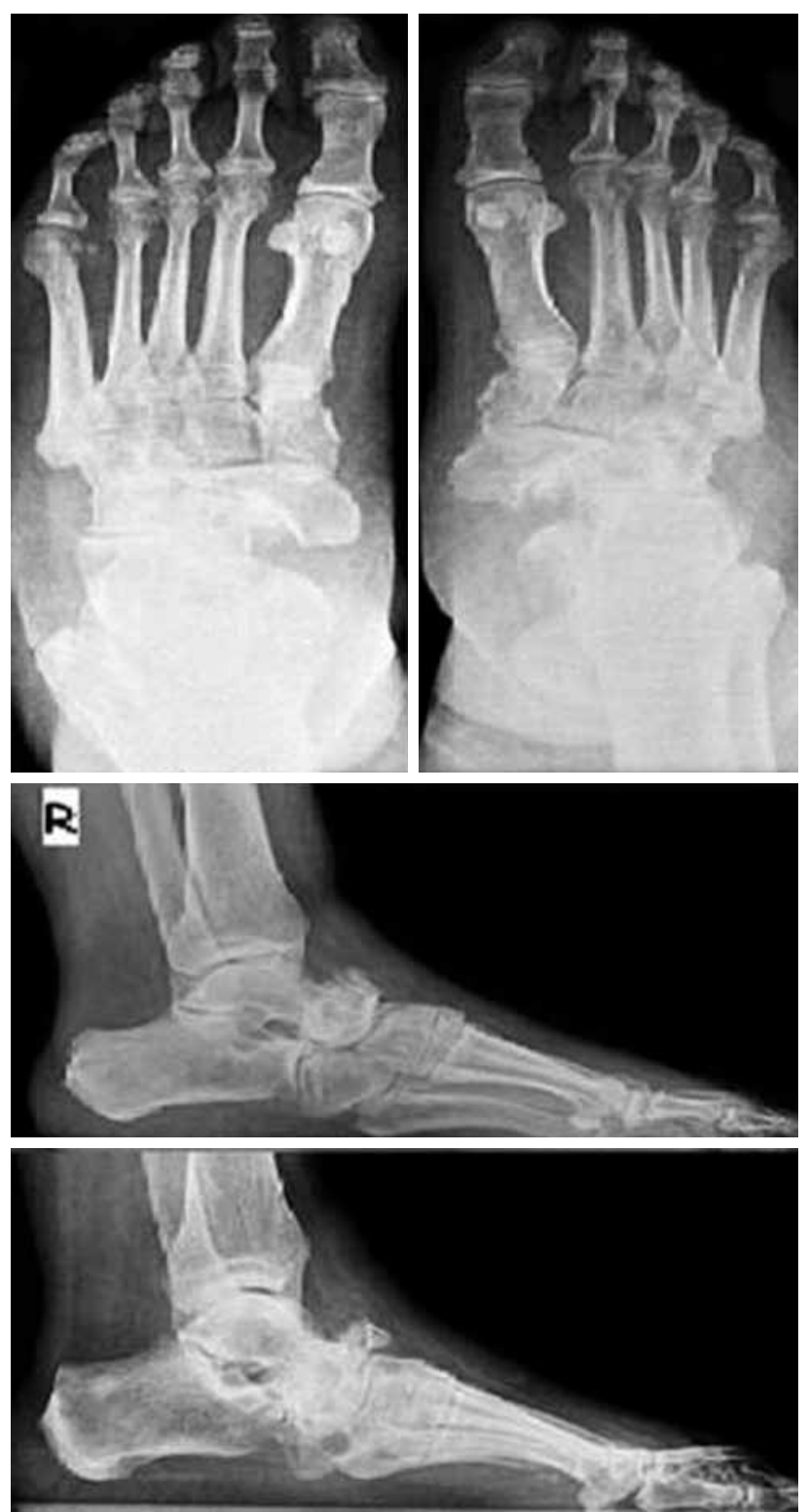

Figure 1. Preoperative, standing anteroposterior and lateral image of both feet showing; subchondral sclerosis, irregularity, narrowing of the talonavicular joint, apparent osteophyte formation and comma-like shaped navicular bone due to decreased coverage of the navicula. 

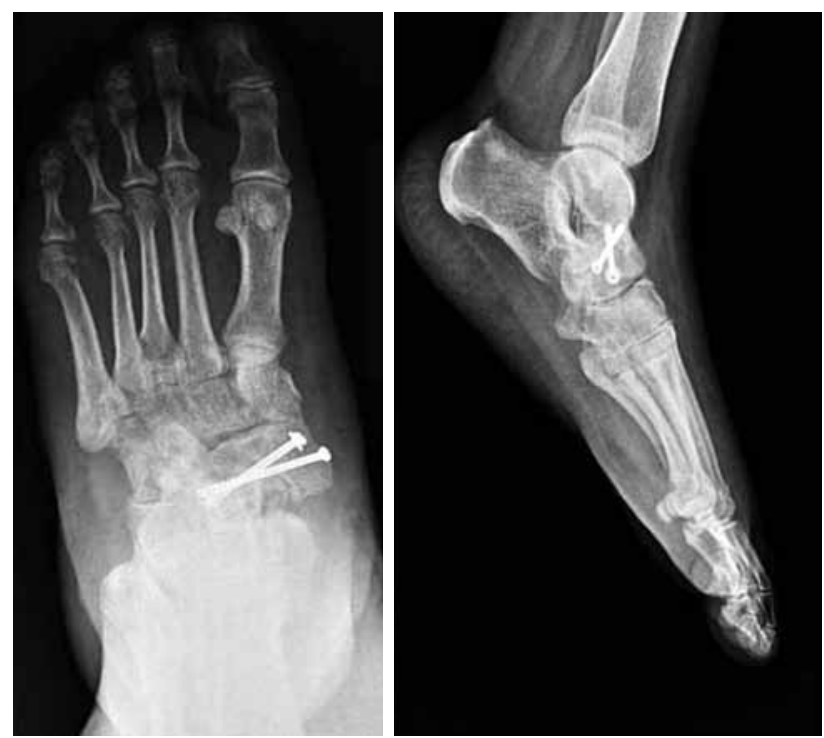

Figure 2. Postoperative seventh month image of left foot following curettage, autogenous grafting and talonavicular joint arthrodesis with cannulated screws.

arteria, absence of secondary blood supply and limited intraosseous anastomosis, there is no apparent characteristic micro and macro circulation of the navicular bone. Trauma is known to be the major etiological factor $(75 \%)$, but foot deformities such as pes planovalgus, systemic diseases (diabetes, lupus), drugs (steroids, antineoplastic), and excessive alcohol consumption are also known to be the factors that lead to AVN of the tarsal bones. ${ }^{[7,8]}$ None of the abovementioned etiological factors were present in this case with bilateral AVN of both the talus and the navicula. Spontaneous osteonecrosis of the navicular bone is a rare condition and shows a bimodal age pattern. Koehler's disease was defined as a self-limiting disease characterized with AVN of the navicular bone while Müller-Weiss was described as a similar clinical entity with distinctive features such as spontaneous bilateral osteonecrosis of the navicular bone, which usually does not resolve by itself. ${ }^{[9,10]}$

In Müller-Weiss disease, the lateral aspect of the navicula is prominently affected, compared to medial aspect, and thus a plastic deformation occurs in this localization, which apparently increases the predisposition for rigid pes planus. In the presented case, a sclerotic collapse can be seen in the lateral aspect of the navicula in conventional standing anteroposterior radiographs. The collapse in the lateral aspect and prominence of the medial aspect give navicula a comma-like shape. This comma-like shaped navicula is described to be a demonstrative radiographic appearance in Müller-Weiss disease. ${ }^{[1]}$
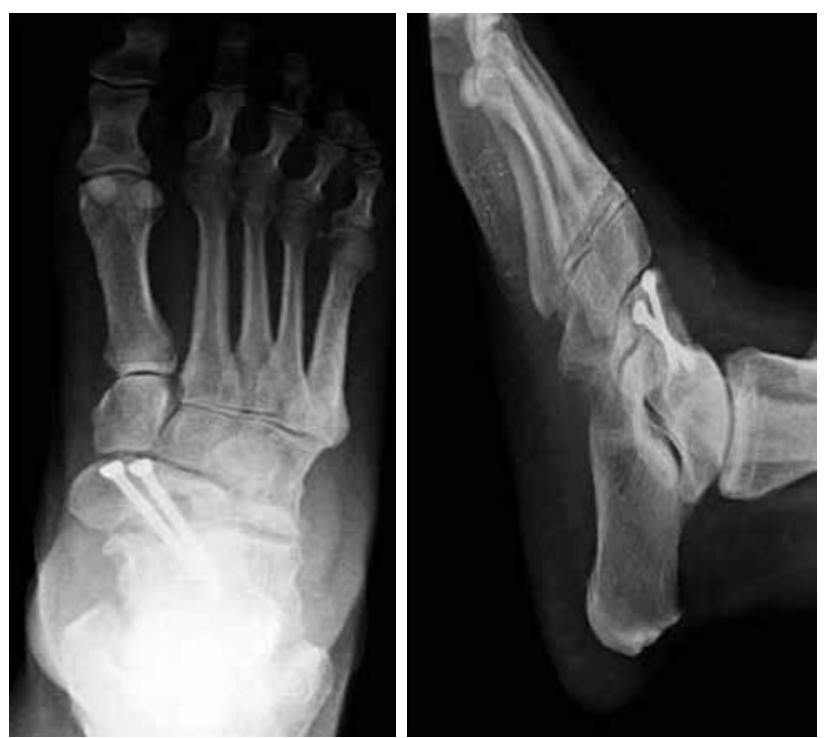

Figure 3. Postoperative first month image of the right foot following curettage, autogenous grafting and talonavicular joint arthrodesis with cannulated screws.

Lateral radiographs that reveal apparent osteophyte formation have to be distinguished from an avulsion fracture or os supranaviculare, especially if the patient is young and is related to sports activities. ${ }^{[12]}$

In talonavicular joint problems, the functional results in isolated talonavicular arthrodesis are recently reported to be superior, compared to the conventional triple arthrodesis that leads to increased tension loads that occur between navicula, talus and cuneiforms. ${ }^{[13,14]}$ In this case, after applying a twostage bilateral isolated talonavicular arthrodesis, the patient was pain free and at the end of 12 weeks and she was able to ambulate independently while full weight-bearing. A thorough radiological consolidation was detected at the talonavicular joint at sixth month. Cases with isolated talonavicular arthrosis described in the literature are generally cases with inflammatory, rheumatological and trauma etiologies, whereas the presented case is a rare one in terms of talonavicular degenerative arthritis as a consequence of spontaneous AVN of the navicula and talus. ${ }^{[15-17]}$ The entire clinical and radiological features of the presented case were found to be concordant with Müller-Weiss disease.

In conclusion, spontaneous and bilateral AVN of the navicular bone and advanced bilateral talonavicular arthrosis, especially in women, should arouse suspicion for Müller-Weiss disease. In such cases, to avoid the development of rigid pes planus and to achieve a painless plantigrade 
foot, decancellation of the navicula and filling the defect with autogenous graft combined with isolated talonavicular arthrodesis via cannulated screws are effective treatment modalities.

\section{Declaration of conflicting interests}

The authors declared no conflicts of interest with respect to the authorship and/or publication of this article.

\section{Funding}

The authors received no financial support for the research and/or authorship of this article.

\section{REFERENCES}

1. Chiodo CP, Herbst SA. Osteonecrosis of the talus. Foot Ankle Clin 2004;9:745-55.

2. Schmidt DM, Romash MM. Atraumatic avascular necrosis of the head of the talus: a case report. Foot Ankle 1988;8:208-11.

3. Maceira E, Rochera R. Müller-Weiss disease: clinical and biomechanical features. Foot Ankle Clin 2004;9:105-25.

4. Delanois RE, Mont MA, Yoon TR, Mizell M, Hungerford DS. Atraumatic osteonecrosis of the talus. J Bone Joint Surg [Am] 1998;80:529-36.

5. Mont MA, Schon LC, Hungerford MW, Hungerford DS. Avascular necrosis of the talus treated by core decompression. J Bone Joint Surg [Br] 1996;78:827-30.

6. Atik OŞ. Do not treat the radiograph, treat the patient! Eklem Hastalik Cerrahisi 2015;26:125.

7. de Gheldere A, Ndjoko R, Docquier PL, Mousny M,
Rombouts JJ. Orthopaedic complications associated with sickle-cell disease.Acta Orthop Belg 2006;72:741-7.

8. Adelaar RS, Madrian JR. Avascular necrosis of the talus. Orthop Clin North Am 2004;35:383-95.

9. Boc SF, Feldman G. Bilateral spontaneous avascular necrosis of the navicular. Case presentation with comparative imaging. J Am Podiatr Med Assoc 1998;88:41-4.

10. Greenhagen RM, Crim BE, Shinabarger AB, Burns PR. Bilateral osteonecrosis of the navicular and medial cuneiform in a patient with systemic lupus erythematosus: a case report. Foot Ankle Spec 2012;5:180-4.

11. Adleberg JS, Smith GH. Corticosteroid-induced avascular necrosis of the talus. J Foot Surg 1991;30:66-9.

12. Bayramoğlu A, Demiryürek D, Firat A, Oznur A, Ozsoy MH. Differential diagnosis in a professional basketball player with foot pain: is it an avulsion fracture or an os supranaviculare? Eklem Hastalik Cerrahisi 2009;20:59-61.

13. Main BJ, Jowett RL. Injuries of the midtarsal joint. J Bone Joint Surg [Br] 1975;57:89-97.

14. Chen $\mathrm{CH}$, Huang PJ, Chen TB, Cheng YM, Lin SY, Chiang $\mathrm{HC}$, et al. Isolated talonavicular arthrodesis for talonavicular arthritis. Foot Ankle Int 2001;22:633-6.

15. Chiodo CP, Martin T, Wilson MG. A technique for isolated arthrodesis for inflammatory arthritis of the talonavicular joint. Foot Ankle Int 2000;21:307-10.

16. Kindsfater K, Wilson MG, Thomas WH. Management of the rheumatoid hindfoot with special reference to talonavicular arthrodesis. Clin Orthop Relat Res 1997;340:69-74.

17. Johnstone AJ, Maffulli N. Primary fusion of the talonavicular joint after fracture dislocation of the navicular bone. J Trauma 1998;45:1100-2. 